\title{
WIARA JAKO ZASADNICZY WARUNEK PRZYJECIA SAKRAMENTU CHRZTU
}

Treść: Wstęp. - 1. Aspekt historyczny problemu. - 2. Wiara w ujęciu teologicznym. - 3. Problem wiary katechumena, rodziców chrzczonego dziecka i chrzestnych w świetle prawa kanonicznego i liturgicznego. - 3.1. Osoba dorosła przystępująca do chrztu. - 3.2. Rodzice proszący o chrzest swojego dziecka. - 3.3. Chrzestni. Zakończenie.

\section{Wstęp}

Sakrament chrztu stanowi fundament życia chrześcijanina, od jego przyjęcia to nowe życie właściwie się zaczyna. Pierwszy z sakramentów wtajemniczenia chrześcijańskiego jest bramą otwierającą dostęp do pozostałych, wyzwala od grzechu, szczególnie pierworodnego. Człowiek niejako rodzi się na nowo, teraz stając się dzieckiem Bożym, zostając wczepionym w Chrystusowy Kościół.

Z chrztem łączy się wiara. Jest ona osobowym aktem człowieka, odpowiadającego na Boże wezwanie. Wspólnota, jaką jest Kościół, prowadzi chrześcijanina drogą wiary, karmi ją i podtrzymuje, aby nie została utracona. Zasadniczo każdy ochrzczony wielokrotnie w swoim życiu składa publicznie wyznanie swojej wiary, wypowiadając odpowiednią formułę, odmawiając modlitwę „Wierzę w Boga”, czy też dając jej świadectwo poprzez postępowanie, „specyficzne”, często różne od zachowań ludzi niewierzących.

Chrzest jest sakramentem wiary. ${ }^{1} \mathrm{~W}$ życiu chrześcijanina wspomniane dwa elementy wzajemnie się przeplatają. Niniejsza publika-

\footnotetext{
${ }^{1}$ Katechizm Kościoła Katolickiego, nr 1253, Poznań 1998; dalej używam skrótu: KKK.
} 
cja porusza ten problem, stanowiąc próbę jego pogłębienia. Dokonuje szczegółowej analizy fenomenu wiary w kontekście chrztu, ukazując równocześnie w sposób syntetyczny, historyczny aspekt omawianej kwestii. Ponadto omawia i interpretuje normy prawne i liturgiczne dotyczące wiary osoby przystępującej do chrztu, rodziców dziecka, pragnących ochrzcić swoje potomstwo oraz chrzestnych.

\section{Aspekt historyczny problemu}

Jezus nakazał swoim uczniom rozejście się po świecie i głoszenie Ewangelii, w tym prawdy wiary o konieczności chrztu do zbawienia. Nauczał, że ten, kto uwierzy i przyjmie chrzest będzie zbawiony. ${ }^{2}$ Warto w tym miejscu zwrócić uwagę na fakt konieczności połączenia chrztu z wiarą przyjmującego. Nakazu tego trzymali się chrześcijanie od początków działalności Kościoła. W tamtych czasach zasadą było udzielanie wspomnianego sakramentu osobom dorosłym. Święty Justyn męczennik $(+165)$ powołując się na autorytet apostołów pisze, iż osoba, która prosi o obmycie wodą w imię Trójcy św., musi wierzyć w naukę Chrystusa, być przekonaną o jej prawdziwości oraz obiecać życie według tej nauki. Tak więc wszyscy którzy doszli do wiary, składali ślubowanie, że będą zgodnie z nią żyli i dopiero wtedy kapłani udzielali im chrztu. ${ }^{3}$ Obrzędy chrztu wymagały wyznania wiary kandydata, złożonego $\mathrm{w}$ formie odpowiedzi na pytanie stawiane przed każdorazowym, trzykrotnym zanurzeniem go w wodzie: „czy wierzysz?”4

Chrzest był poprzedzany przez katechumenat, ze specyfiką przyjęcia formy stanu, bycia chrześcijaninem, ${ }^{5}$ życia zgodnego z wyznawaną wiarą. Gwarancję takiej postawy dawali chrzestni, nazywani wtedy sponsorami, gwarantami, rodzicami duchowymi. Osoby te dzieliły się z katechumenami doświadczeniem swojej własnej wiary. Droga wiary była bowiem eklezjalna, a chrzest ją przypieczętowywał. ${ }^{6}$

${ }^{2}$ Mk 16, 15-16.

3 Apologia, I, 61, PL 6, 420.

4 Tertulian, De baptismo, 4, PL 1, 1219.

5 B. Nadolski, Liturgika. Sakramenty, sakramentalia, błogosławieństwa, t. 3, Poznań 1992, s. 23.

6 Tamże, s. 23-24. 
Wyrazem wyznawanej wiary jest sposób postępowania. Stąd od II wieku kandydaci do chrztu musieli się wykazać, że pozbyli się swoich wcześniejszych obyczajów niezgodnych z nauczaniem Chrystusa i potrafią żyć według zasad wiary. Synod w Neocezarei (ok. 314) zezwalał darowanie ciężkiego grzechu katechumenowi, ale w przypadku, kiedy po odbyciu pokuty ponownie zgrzeszył, zakazywał udzielania mu chrztu. ${ }^{7}$ Według Konstytucji Apostolskich (ok. IV-V w.) niezdatnymi do przyjęcia sakramentu byli rozpustnicy, stręczyciele, uczestnicy zabaw lubieżnych, czarnoksiężnicy, astrologowie i wróżbici. Ponadto do grupy tej zaliczano również żebraków, handlarzy - domokrążców, gladiatorów, aktorów grających w niemoralnych sztukach, sportowców uprawiających brutalne formy zdegenerowanych starożytnych sportów, rzemieślników produkujących przedmioty kultu pogańskiego. Przedstawiciele wymienionych zawodów przed przyjęciem chrztu musieli zmienić pracę. ${ }^{8}$

W pierwszych wiekach interesującego nas sakramentu udzielano również dzieciom. Miało to miejsce podczas chrztu „całego domu”, a więc ojca rodziny, jego małżonki, a nawet niewolników. Według św. Hipolita Rzymskiego (+ ok. 235) dzieci, które osiągnęły używanie rozumu same odpowiadały na pytania stawiane przez celebransa (w tym również o przyjęcie wiary), natomiast za niemowlęta odpowiedzi udzielali ich rodzice. ${ }^{9}$ Takie działanie rodziców wyjaśnia diakon Jan - prawdopodobnie późniejszy papież Jan (523-526) - w liście do Senariusza, dworzanina cesarskiego. W imieniu małych dzieci wiarę wyznają rodzice, lub ci, którzy je przynoszą do chrztu, ponieważ wiara innych pomaga dzieciom do zbawienia, podobnie, jak zaszkodził im grzech innych. ${ }^{10}$ Kwestię tą porusza także św. Izydor z Sewilli (+636) pisząc, że jak za chorych, głuchych albo niemych, inna osoba wypowiada słowa wymagane przy obrzędzie chrztu, tak za niemowlęta

7 Kan. 3, Mansi 2, 549.

8 Constitutiones Apostolorum, VIII, 32, w: F. X. Funk, Didascalia et Constitutiones apostolorum, t. 1, Padeborn 1905, s. 535-537.

9 Traditio apostolica, 21, w: Botte B., La Tradition apostolique de Saint Hyppolyte essai de reconstitution par Dom Bernard Botte, Munster Westfallen 1963, s. 45.

${ }^{10}$ Ioannis diakoni epistola ad Senarium virum illustrum, III, PL 49, 403. 
niepotrafiące mówić i wyznawać wiary, czynią to inni. Postępują tak, ponieważ w przypadku śmierci, bez sakramentu dzieci nie mogłyby się zbawić. ${ }^{11}$ Beda Venerabilis (+735) komentując Pismo św. dodaje, iż wiara rodziców wspomaga ich dzieci. ${ }^{12}$ A Amalariusz z Metzu (+ ok. 850) w liście do cesarza Karola Wielkiego wyjaśnia, że chociaż niemowlęta nie mogą przeżywać swojego nawrócenia i wzbudzać w sobie aktów wiary, to sakrament chrztu sprawia, że mają one wiarę i są miłe Bogu. ${ }^{13}$ Ostateczne rozstrzygnięcie dotyczące chrztu dzieci, wypracował Sobór Trydencki, podczas piątej sesji w 1546 r. Odrzucił wtedy opinię, według której nie można ich chrzcić, ponieważ nie są w stanie wyznać wiary przy sprawowaniu obrzędu przyjęcia sakramentu. Ich własny akt wiary zastępuje bowiem wiara Kościoła. ${ }^{14}$

Przyjęcie wiary chrześcijańskiej łączyło się z umiejętnością słownego jej wyrażania. Stąd angielski Synod w Celchyt (787 r.) domagał się od dopuszczanych do sakramentu przynajmniej ogólnej znajomości „Składu Apostolskiego” i modlitwy „Ojcze nasz”. ${ }^{15}$ Hincmar z Reims (+882) wyjaśnia, że przed przyjęciem chrztu, należy poznać wiarę i według niej żyć. ${ }^{16}$ Natomiast Hugo od św. Wiktora $(+1141)$ stwierdza, że naucza się katechumenów, aby przekazać im wiedzę o wierze i ją w nich wzbudzić. ${ }^{17}$ Papież Aleksander VII (1655-1667) zakazuje misjonarzom w Azji chrztu kandydatów niedostatecznie pouczonych, którzy na skutek ignorancji mieszają prawdziwą wiarę $\mathrm{z}$ bałwochwalstwem, a prawo Chrystusa $\mathrm{z}$ instytucjami pogańskimi. ${ }^{18}$ Natomiast Kongregacja Rozkrzewiania Wiary w piśmie z 13 września 1760 r. nakazuje pouczanie katechumenów o ich obowiązkach, wypływających

${ }^{11}$ De ecclesiasticis officiis, II, 25, 7, PL 83, 822.

${ }^{12}$ In Marcum, 7, PL 92, 203.

${ }^{13}$ Epistola ad Carolum imperatorem de scrutinio et baptismo, PL 99, 899.

${ }^{14}$ Sess. VII, Canones de sacramento baptismi, kan. 13, Dokumenty soborów powszechnych. Tekst grecki, łaciński, polski, opr. A. Baron, H. Pietras, t. 4, Kraków 2004, s. 362-363.

${ }^{15}$ Cap. 2, Mansi 12, 939.

${ }^{16}$ Epistola XVIII, PL 126, 105.

${ }^{17}$ De sacramentis, lib. II, pars IV, cap. 9, PL 176, 456.

${ }^{18}$ Magnum Bullarium romanum a Beato Leone Magno usque ad S.D.N. Benedictum $X I V$, Luxemburgi 1742, s. 63. 
z wiary i dopuszczanie do sakramentu po długim katechumenacie, podczas którego okażą wyraźne oznaki prawdziwej i żywej wiary oraz stałości w wyznawaniu religii chrześcijańskiej, bez względu na pojawiające się trudności życiowe. ${ }^{19}$

Wykaz tematów, z którymi należało zapoznać katechumenów, opublikowała Kongregacja Rozkrzewiania Wiary 18 października $1883 \mathrm{r}$. Kandydaci do chrztu powinni znać główne prawdy wiary, Skład Apostolski, Modlitwę Pańską, przykazania Boże i kościelne, skutki chrztu, akty wiary, nadziei i miłości oraz ważniejsze obrzędy. ${ }^{20} \mathrm{Nie}$ wystarczała jednak tylko teoretyczna znajomość prawd wiary, konieczne było również ich przestrzeganie w życiu. Stąd Kongregacja św. Oficjum 28 marca 1860 r. stwierdza, iż przyjmujący interesujący nas sakrament musi wcześniej porzucić konkubinat lub związek poligamiczny. Kościół nigdy nie odstępuje od takich zasad, ponieważ „nie można pogodzić światła z ciemnością". ${ }^{21}$

Reasumując należałoby stwierdzić, że w myśl tradycji i nauczania Kościoła, przyjęcie pierwszego z sakramentów wtajemniczenia chrześcijańskiego powinno być poprzedzone odpowiednim przygotowaniem, połączonym ze wzbudzeniem u kandydata cnoty wiary, z której wypływa chrześcijański sposób życia. Przystąpienie do chrztu bez wiary i żalu za dotychczas popełnione grzechy, czyni takie postępowanie niegodziwym. ${ }^{22}$

\section{Wiara w ujęciu teologicznym}

Od początków Kościoła chrzest i wiara wzajemnie się przenikały. Czym jest zatem cnota wiary, jedna z trzech cnót kardynalnych, obok nadziei i miłości? Myśliciele średniowieczni, w tym św. Augustyn i Piotr Lombard byli przekonani, że chrzest musi być poparty przez ogólny ślub wiary chrześcijańskiej. ${ }^{23}$ Św. Tomasz z Akwinu wymaga

\footnotetext{
${ }^{19}$ I. SEREdI, Fontes, vol. VII, n. 4537, p. 79.

${ }^{20}$ Tamże, n. 4903, p. 506, n. XVII.

${ }^{21}$ P. Gasparri, Fontes, vol. IV, n. 957, p. 233.

${ }^{22}$ Kongregacja św. Oficıum, Instrukcja, 1.08.1860, w: P. Gasparri, Fontes, vol. IV, n. 963 , p. $236-237$.

${ }^{23}$ K. Demmer, Podstawowe elementy antropologii chrześcijańskiej, w: Perspektywy teologii moralnej, tłum. T. Mieszkowski, Warszawa 1982, s. 96.
} 
od wierzącego wiary, jako świadczenia, czyli spełniania określonych obowiązków, zatem heretyk według niego, winien być ukarany, jako fałszywy świadek. ${ }^{24}$ Ten kierunek, jak się wydaje, został przyjęty przez Sobór Watykański I, który nauczał, że wiara jest cnotą nadprzyrodzoną, przez którą wierzy się, pod wpływem natchnienia i z pomocą łaski Bożej, że prawdą jest to, co Bóg objawił. Sama w sobie jest darem Boga, a akt wiary, to działanie odnoszące się do zbawienia, przez które człowiek wyraża dobrowolne posłuszeństwo wobec Stwórcy, zgadzając się i współpracując z Jego łaską, chociaż mógłby się jej przeciwstawić. Wiarą boską i katolicką należy wierzyć we wszystko, co jest zawarte w Słowie Bożym spisanym i przekazanym i jest do wierzenia przedkładane przez Kościół, natomiast ci, którzy przyjęli wiarę w ramach magisterium Kościoła, nie mogą ją poddawać w wątpliwośćc ${ }^{25}$

Trzeba jednak wyraźnie podkreślić, że wiara jest nie tylko suchym przyjęciem formuł katechizmowych, ale osobistym spotkaniem z Bogiem. Nawet wtedy, gdy dla ludzkiego umysłu stanie się jasne, że Bóg istnieje, nie będzie on wiedział, kim jest Bóg, nie będzie wiedział o Nim nic bliższego, ponieważ Bóg całkowicie pojmowany ludzkim umysłem nie byłby już Bogiem. Możliwym staje się uchwycenie poszczególnych momentów wiary. Jest ona poznaniem i uznaniem. Ludzki rozum posuwa się do ostatecznych swoich granic w słuchaniu, poznawaniu i przemyśliwaniu tajemnic Bożych. Wola przyporządkowuje się żądaniom Stwórcy, wyciągając konsekwencje dla osobistego życia człowieka. Wiara nie stanowi ani wyniku wnioskowania, ani też podejmowanego „w ciemno” ryzyka, ponieważ człowiek nie rzuca się na ślepo w irracjonalizm. Wiara dotyka serca, jako centrum ludzkiej osoby, z którego wywodzą się właściwe decyzje. W swojej istocie jest łaską, jeśli Bóg nie zbliży się do człowieka, jego własne wysiłki na nic się nie zdają. Bóg jednak nie przymusza do wiary, zaczyna swoje działanie, w chwili pojawienia się u człowieka pytań, tęsknoty i gotowości.

${ }^{24}$ Summa theologiae, 2, II q. 10 a. 8; q. 11 a. 3.

${ }^{25}$ Sess. III, Constitutio dogmatica de fide catholica, 24.04.1870, cap. 3, Dokumenty soborów powszechnych. Tekst grecki, łaciński, polski, opr. A. Baron, H. Pietras, t. 4, Kraków 2004, s. 896-899. 
Wiara jest wydarzeniem dokonującym się w spotkaniu Boga z człowiekiem. Jej proces urzeczywistnia się etapami, poczynając od usłyszenia i zrozumienia, poprzez postanowienie i decyzję woli, a kończąc na całkowitym zdaniu się na Boga spotykanym w Jezusie Chrystusie. ${ }^{26}$

Katechizm Kościoła Katolickiego ujmuje to w następujący sposób. Wiara to najpierw osobowe przylgnięcie człowieka do Boga i dobrowolne uznanie całej prawdy objawionej. Różni się zatem od wiary w osobę ludzką. Dla chrześcijanina wiara w Boga jest nieodłączna od wiary w Tego, którego On posłał - Jesusa Chrystusa, natomiast nie można wierzyć w Syna Bożego, nie mając udziału w Jego Duchu, który objawia ludziom, kim jest Jezus. Wiara to akt autentycznie ludzki. Okazanie zaufania Stwórcy i przylgnięcie do prawd objawionych, nie jest przeciwne wolności ani rozumowi ludzkiemu. W wierze rozum i wola człowieka współdziałają z łaską Bożą. ${ }^{27}$

Jaka jest relacja wiary do przyjmowanych przez człowieka sakramentów? Sakramenty zakładają wiarę, a przy pomocy słów i rzeczy dają jej wzrost, umacniają ją i wyrażają, stąd są nazywane sakramentami wiary. ${ }^{28} \mathrm{Nie}$ jest ona jednak aktem wyizolowanym, wierzący otrzymuje ją od innych, a dokładniej dzięki Kościołowi przez sakrament chrztu. Wiara Kościoła poprzedza późniejszy akt człowieka, który zostaje wezwany do przyjęcia Bożego orędzia. Kiedy Kościół celebruje sakramenty, wyznaje wiarę otrzymaną przed wiekami od apostołów. ${ }^{29}$ Wiarę dostaje człowiek na chrzcie, nie w sposób, żeby nie mógł jej utracić, ale dana mu jest ona jako pewne zadanie, zdatność, którą należy rozwinąć do sprawności. ${ }^{30}$ Chrzest udziela wiary, która zarazem jest owocem chrztu. Pojawia się tu jednak problem teologiczny: akt chrztu poprzedzony jest wyznaniem wiary, która pochodzi ze słuchania nauczania Chrystusowego. Chrzest stanowi zatem cel, do którego prowadzi droga wiary, zgodnie zresztą ze słowami Jezusa: „kto uwierzy i przyjmie chrzest, będzie zbawiony, a kto nie uwierzy, będzie potępio-

\footnotetext{
${ }^{26}$ F. KRenzer, Taka jest nasza wiara, thum. F. Wycisk, Paris 1981, s. 83-84.

${ }^{27}$ KKK, nr 150-152; 154-155.

${ }^{28}$ Tamże, nr 1123.

${ }^{29}$ Tamże, nr. $166 ; 168 ; 1124$.

${ }^{30}$ W. KRENZER, dz. cyt., s. 89.
} 
ny"(Mk 16, 16). ${ }^{31}$ Wiara i chrzest należą do siebie nierozerwalnie. Ona prowadzi do chrztu, a ten stanowi szczytową formę jej ucieleśnienia. Wiara jest drogą i dyspozycją umożliwiającą przyjęcie chrztu. A zatem, jak zauważa A. Skowronek, wiara wyprzedza chrzest i mu towarzyszy. ${ }^{32}$ Tak więc, jak się wydaje, wiara otrzymywana przy chrzcie, a równocześnie niejako poprzedzająca ten sakrament, dotyczy przede wszystkim małych dzieci, które nie są w stanie wzbudzić jej, zanim zostaną ochrzczone. W przypadku dorosłych, Kościół wymaga jej wzbudzenia, jeszcze przed chrztem, który później ją potęguje i wzmacnia.

Wiara ukazywana przez Nowy Testament polega na zetknięciu się człowieka z Chrystusem. Jako warunek jest tutaj postulowana metanoia, czyli radykalna przemiana ludzkiego serca, wymagająca konsekwencji i naśladowania Mistrza. Albowiem wiara to relacja do Boga, obejmująca całego człowieka, z całym jego zewnętrznym zachowaniem i życiem wewnętrznym. ${ }^{33}$ Akt wiary dokonuje się w postawie intelektualnej człowieka, uznającego za prawdę Boże objawienia i tradycję Kościoła oraz powierzeniu się Bogu w zaufaniu i miłości, z zaangażowaniem wszystkich wewnętrznych władz duchowych i pójściem za głosem wiary, żądającej wewnętrznej przemiany życia, czyli nawrócenia. Wiara jest zatem nieodwołalnym zaangażowaniem się po usłyszeniu Ewangelii i jej aktywnym przyjęciem poprzez nawrócenie. ${ }^{34}$

Wiara bez uczynków martwa jest, jak naucza w swoim liście św. Jakub apostoł. ${ }^{35}$ Jakie mają być te uczynki? Polegają one na naśladowaniu Chrystusa. Nie znaczy to, że należy Go kopiować. Wystarczy kochać i służyć bliźnim, tak jak On to czynił. Jego przykład jest pewnym miernikiem, modelem postępowania, stanowiąc rzeczywistość otwartą, urzeczywistnianą odpowiednio do swoistych właściwości i zdolności człowieka i epoki w której przychodzi mu żyć. Wymagania Ewangelii nie pozwalają nigdy na stan spoczynku, nakazują postępo-

${ }^{31}$ A. SkowroneK, Z teologii chrztu, w: Sakrament chrztu. Liturgia, teologia, Pismo św., Katowice 1973, s. 11-12.

${ }^{32}$ Tamże, s. 15-16.

${ }^{33}$ W. Krenzer, dz. cyt., s. 85.

${ }^{34}$ A. SkowroneK, dz. cyt., s. 13-14.

$35 \mathrm{Jk}, 2,20$. 
wać naprzód, bo kto zmienia siebie, zmienia cały świat. Ta ciągła przemiana ku temu, co dobre, będąca wyrazem wiary człowieka, jest celem jego chrześcijańskiego życia. ${ }^{36}$

Jakie są zatem prawdy wiary, konieczne do przyjęcia przez człowieka przed chrztem? Ich syntetyczne streszczenie podaje M. Pastuszko. Należy wierzyć we wszystkie objawione prawdy Boże, nie wymaga się jednak wyraźnej wiary w każdą z nich szczegółowo. Wystarczy uznanie ich implicite, aktem pośrednim i niewyraźnym. Chociaż istnieją podstawowe prawdy wiary w stosunku do których, konieczne jest przyjęcie ich wyraźne i bezpośrednie. Są nimi, jak się wydaje, ${ }^{37}$ wiara w istnienie Boga, w jego sprawiedliwość, wyrażającą się w wynagradzaniu i karaniu ludzkich uczynków, w tajemnicę Trójcy św. i Wcielenia Syna Bożego. Streszczenie prawd wiary znajdujemy w Symbolach wiary, stanowiących niejako jej streszczenie, spisane przede wszystkim dla kandydatów do przyjęcia chrztu. ${ }^{38}$ Wykład wiary, oparty na Symbolu Apostolskim, prezentuje Katechizm Kościoła Katolickiego. ${ }^{39}$

\section{Problem wiary katechumena, rodziców chrzczonego dziecka i chrzestnych w świetle prawa kanonicznego i liturgicznego}

Po syntetycznym zapoznaniu się z historycznym ujęciem interesującej nas kwestii oraz teologicznym spojrzeniem na fenomen wiary człowieka, przejdźmy do szczegółowej analizy w odniesieniu do osób, od których prawo kanoniczne wymaga wiary, przy okazji sprawowania sakramentu chrztu.

\subsection{Osoba dorosła przystępująca do chrztu}

Człowiek dorosły pragnący przyjąć pierwszy z sakramentów wtajemniczenia chrześcijańskiego, w swojej motywacji zazwyczaj kieruje się wiarą. W XXI stuleciu już raczej nie spotyka się przypadków przy-

${ }^{36}$ W KRENZER, dz. cyt., s. 247-248.

${ }^{37}$ M. Pastuszko, Prawo o sakramentach świętych. Normy ogólne i sakrament chrztu, t. 1, Warszawa 1983, s. 188.

${ }^{38} \mathrm{KKK}, \mathrm{nr} 186-187$.

${ }^{39}$ Tamże, nr 199-1065. 
muszania kogoś do chrztu. Tym bardziej, że sakramentu nie udziela się natychmiast po wyrażeniu przez takiego człowieka woli jego otrzymania, ale po długim okresie przygotowania, nazywanym katechumenatem. Sposób odbywania katechumenatu został określony w księdze liturgicznej - w Obrzędach chrześcijańskiego wtajemniczenia dorostych, wydanej po Soborze Watykańskim II w 1972 r.

Dorośli, po usłyszeniu przepowiadania tajemnicy Chrystusa i pod wpływem działania Ducha św., który otworzył ich serca, świadomie i dobrowolnie szukają Boga i wstępując na drogę wiary rozpoczynają okres katechumenatu. ${ }^{40}$ Kodeks prawa kanonicznego stanowi, że powinni oni wyrazić wolę przyjęcia chrztu, zostać odpowiednio pouczeni o prawdach wiary i obowiązkach chrześcijańskich, przejść próbę życia chrześcijańskiego oraz zostać zachęceni do skruchy za swoje osobiste grzechy. ${ }^{41}$

Czas katechumenatu ma między innymi na celu nauczyć ich wyznawać wiarę i modlić się, przy wsparciu przykładu i pomocy wiernych poręczających za nich i rodziców chrzestnych. ${ }^{42}$ Przygotowanie do chrztu zawiera również tak zwany okres oczyszczenia i oświecenia. W tym czasie katechumeni koncentrują się bardziej na skupieniu ducha, niż na katechizacji oraz przystępują do skrutiniów, podczas których przekazywane im są dokumenty wiary i modlitwy. Jeżeli wcześniej nie nastąpiło przekazanie „Symbolu wiary”, sprawuje się je w ciągu tygodnia po pierwszym skrutinium. „Symbol wiary” powinien być przez nich opanowany pamięciowo. Przed samym obrzędem chrztu bierzmowania i Eucharystii katechumeni składają wyznanie wiary. ${ }^{43}$

Oceniając przygotowanie katechumena do chrztu, zwłaszcza znajomości prawd wiary, należy uwzględnić konkretne warunki, w jakich się on znajduje, czyli zdolności, poziom rozwoju intelektualnego, śro-

${ }^{40} \mathrm{KL}, 64-66$.

${ }^{41}$ Kan. 865, par. 1.

${ }^{42}$ Rituale Romanum ex decreto Sacrosancti Oecumenici Concilii Vaticani II instauratum auctoritate Pauli PP VI promulgatum. Ordo initiationis christianae adultorum. Praenotanda, nr 20, Editio typica, Typis Polyglottis Vaticanis 1972, reimpressio emendata 1974.

${ }^{43}$ B. NAdolski, dz. cyt., s. 46; 48. 
dowisko w jakim żyje. Do tego wszystkiego należy dostosować wymagania. Jeżeli kandydat szczerze pragnie przyjąć chrzest i w miarę swoich możliwości spełnia stawiane przez Kościół wymagania, dotyczące znajomości prawd wiary, obowiązków oraz życia chrześcijańskiego, powinien być dopuszczony do sakramentu. ${ }^{44}$ Mniejsze wymogi są stawiane dorosłemu, znajdującemu się w niebezpieczeństwie śmierci. Wystarcza wtedy, że posiada nawet ogólną i jeszcze nie ugruntowaną znajomość głównych prawd wiary i przyrzeka zachowywać przykazania religii chrześcijańskiej. ${ }^{45}$

Dorosły przystępujący do chrztu, o ile jest to możliwe, powinien mieć chrzestnego, który towarzyszy mu w chrześcijańskim wtajemniczeniu. ${ }^{46}$ Ponadto ma on za zadanie wobec Kościoła zaświadczyć o wierze kandydata. ${ }^{47}$ Cytowana norma zakłada oczywiście wiarę chrzestnego, czemu daje wyraz kan. 874.

Podczas dopuszczania osoby dorosłej do interesującego nas sakramentu najczęściej nie ma większych problemów z uznaniem, że posiada on wymaganą wiarę. Weryfikacja następuje podczas katechumenatu, kiedy jest wystarczająca ilość czasu, aby się mu przypatrzeć. Ponadto wola zostania chrześcijaninem, jest zazwyczaj poprzedzona wiarą. W przypadku niedostatecznego poziomu wiary, braku jej dojrzałości, należy zintensyfikować działania pastoralne, zmierzające do głębszego poznania doktryny Kościoła i przyjęcia jej swoim życiem przez kandydata.

\subsection{Rodzice proszący o chrzest swojego dziecka}

Niemowlęta przynoszone do chrztu nie posiadają jeszcze rozwiniętej wiary, jaka jest wymagana przez Kościół od osób dorosłych. Jednak jak to już zostało wspomniane wcześniej, od II w. dopuszczano je do

${ }^{44}$ P. HempereK, Uświęcające zadanie Kościoła, w: Komentarz do Kodeksu prawa kanonicznego z 1983 r., t. 3, Lublin 1986, s. 89.

${ }^{45}$ Kan. 865, par. 2.

${ }^{46}$ Kan. 872.

${ }^{47}$ J. KRZYwDA, Sakramenty, w: Komentarz do kodeksu prawa kanonicznego, t. III/2, Poznań 2011, s. 59. 
sakramentu. Rękojmię wiary wyrażali za nie rodzice i chrzestni. Tak jest i dzisiaj. Podczas ceremonii chrztu celebrans przypomina rodzicom, że spoczywa na nich obowiązek wychowania potomstwa w wierze Kościoła, obejmujący troskę o ochronę życia Bożego od skażenia grzechem i jego rozwój. Rodzice również składają wyznanie wiary, czyniąc to nie w imieniu dzieci, ale we własnym, w poczuciu odpowiedzialności, za ich wychowanie w tej wierze. ${ }^{48}$

Zatem dziecko otrzymuje chrzest w wierze swoich rodziców i Kościoła. Wyznanie wiary jest połączone w liturgii w jedno, z wyrzeczeniem się zła, za pomocą stałego wprowadzenia przez szafarza sakramentu. Rodzice publicznie wyrzekają się grzechu, aby żyć w wolności od niego jak Boże dzieci, wyrzekają się wszystkiego co prowadzi do zła, aby ich nie opanował grzech, a także szatana, sprawcy grzechu. ${ }^{49}$ Takie wyrzeczenie, będące konsekwencją wyznawanej wiary, powinno być złożone szczerze i rzeczywiście, a nie jedynie formalnie, bez wewnętrznego przekonania. Duszpasterz zatem musi zwrócić uwagę, czy postawa życiowa rodziców uzasadnia do publicznego złożenia opisanej deklaracji. Równocześnie wyznanie wiary nie jest tylko sprawdzeniem istnienia warunku do udzielenia pierwszego sakramentu wtajemniczenia chrześcijańskiego. Wiara usprawiedliwiająca dochodzi do szczytu przez sakramentalne działanie, w chrzcie otrzymuje swoją definitywną formę. A ponieważ pan Bóg zbawia we wspólnocie i przez wspólnotę, omawiany element musi być szczególnie podkreślony przez publiczne działanie. Trzykrotne pytanie rodziców o wiarę i jej wyznanie, jest wyjściem ku Bożemu usprawiedliwieniu. ${ }^{50}$ Znamiennym jest fakt, że tekst normy liturgicznej nie wymaga od rodziców jedynie formalnego wyznania wiary, nie popartego rzeczywistymi ich przekonaniami. W przypadku bowiem, gdy któreś z nich nie może złożyć takiego wyznania, bo na przykład nie jest katolikiem, albo w ogóle osobą niewierzącą, ma prawo do zachowania milczenia. Żąda się

\footnotetext{
${ }^{48}$ S. CZERWIK, Wprowadzenie do odnowionego chrztu dzieci, w: Sakrament chrztu. Liturgia, teologia, Pismo św., Katowice 1973, s. 102-104.

${ }^{49}$ Obrzędy chrztu dzieci wedtug Rytuatu Rzymskiego, Katowice 1972, s. 48.

${ }^{50}$ B. NAdolski, dz. cyt., s. 42-43.
} 
jedynie od takiego rodzica, aby wyrażając prośbę o chrzest swojego dziecka, zamierzał lub się przynajmniej zgadzał, na jego wychowanie według wiary otrzymanej na chrzcie. ${ }^{51}$

Prawodawca kościelny nakłada w omawianej materii specjalne zadanie na proboszcza. Musi on dopilnować, aby składający wyznanie wiary, mogli dokonać tego aktu naprawdę i szczerze, a nie tylko formalnie. ${ }^{52}$ Autentyczna wiara musi więc najpierw istnieć u rodziców chrzczonego dziecka. Kiedy proboszcz przypuszcza, że niemowlę jest przynoszone do sakramentu tylko dla podtrzymania zwyczaju, istniejącego w społeczeństwie, powinien się zastanowić, czy zgoda na chrzest nie jest akceptacją przyjęcia do Kościoła osoby, która w przyszłości, z powodu braku katolickiego wychowania w swojej rodzinie, będzie tylko formalnie przynależeć to Wspólnoty, a może nawet zdecyduje się na faktyczne z niej odejście, jak to się coraz częściej zdarza. ${ }^{53}$

Kościół, który dopuszcza do chrztu i go udziela, jest uprawniony i zobowiązany stać na straży zasad wiary i w związku z tym stawiać pewne wymagania proszącym o chrzest dla swojego potomstwa. U podstaw tych wymagań znajduje się ścisły związek chrztu z wiarą. Stąd też przedstawiciele tegoż Kościoła - duszpasterze, mają prawo i obowiązek badać, czy zachodzą rzeczywiste przesłanki ku istnieniu uzasadnionej nadziei katolickiego wychowania dzieci w wierze. ${ }^{54}$ W przypadku braku takiej nadziei, chrzest należy odłożyć, powiadamiając rodziców o przyczynie. ${ }^{55} \mathrm{~W}$ praktyce, ocena sytuacji nie jest wcale taka łatwa. Szczegółowe wskazania dotyczące tej kwestii podaje instrukcja Kongregacji Nauki Wiary Pastoralis actio, z 22 listopada $1980 \mathrm{r}^{56}$ Dokument stanowi między innymi, że należy zapewnić rozwój daru sakramentalnego przez prawdziwe wychowanie w wierze

${ }^{51}$ Obrzędy chrztu dzieci wedtug Rytuału Rzymskiego..., s. 22.

${ }^{52}$ Wprowadzenie teologiczne i pastoralne, nr 3, Obrzędy chrztu dzieci wedtug Rytuatu Rzymskiego..., nr 4-6, s. 10-11.

${ }^{53}$ Z. JANCZEWSKI, Dopuszczenie do chrztu niemowlat $w$ aspekcie odpowiedzialności za Kościół, Annales Canonici 2(2006), s. 119-120.

${ }^{54}$ P. Hemperek, dz. cyt., s. 92; Kan. 868 par. 1, nr 1-2.

${ }^{55}$ Kan. 868 par. 2.

${ }^{56}$ AAS 72(1981), s. 1137-1157. 
i życiu chrześcijańskim, aby chrzest mógł osiągnąć pełnię swojej rzeczywistości. ${ }^{57}$

Nadzieja katolickiego wychowania dziecka musi być według zamysłu ustawodawcy uzasadniona. Duszpasterz sprawdzając spełnianie przez rodziców tego istotnego warunku, powinien przed wyrażeniem zgody na chrzest dowiedzieć się, czy żyją oni jak prawdziwi chrześcijanie w małżeństwie sakramentalnym, czyli zgodnie z deklarowaną wiarą, czy wypełniają przynajmniej podstawowe obowiązki religijne wobec Boga, czy ich postawa życiowa nie stanowi zgorszenia dla rodziny i środowiska. ${ }^{58} \mathrm{~W}$ przypadku małżeństw niesakramentalnych, należy zwrócić szczególną uwagę na atmosferę religijną w ich rodzinie. W sytuacji konkubinatu rodziców, czyli postawy sugerującej odrzucanie konieczności zawarcia sakramentalnego małżeństwa, wynikającej z wiary w takie wymaganie stawiane przez samego Jezusa, nie występuje, jak się wydaje, uzasadniona nadzieja katolickiego wychowania ich potomstwa. Obowiązkiem duszpasterza jest najpierw próba doprowadzenia konkubinariuszy do przyjęcia wiary swoim życiem i w konsekwencji do zawarcia sakramentalnego małżeństwa. W przypadku niepowodzenia takich działań, należy rozważyć odłożenie chrztu dziecka do czasu zmiany postawy religijnej rodziców. Bo tak jak to już zostało wspomniane, właśnie rodzice deklarują wiarę zamiast dzieci i między innymi w ich wierze następuje chrzest. Podczas podejmowania decyzji o odłożeniu chrztu, należy wziąć pod uwagę prawodawstwo partykularne. ${ }^{59}$

W Polsce omawianą kwestię reguluje Instrukcja duszpasterska Episkopatu o udzielaniu chrztu św. dzieciom z dn. 14-15 grudnia 1977 r. ${ }^{60}$ Dokument stanowi, aby starać się odłożyć chrzest dziecka, do czasu zawarcia przez jego rodziców małżeństwa sakramentalnego. W przypadku wyraźnej odmowy należy żądać od rodziców pisemnego oświadczenia, że wychowają potomstwo w wierze katolickiej. Takie

57 Tamże, nr 28.

${ }^{58}$ Z. JANCZEWSKI, dz. cyt., s. 126.

${ }^{59} \mathrm{KPK}$, kan. 868 par. 2.

${ }^{60}$ Została opublikowana m.in. w: Wiadomości Archidiecezji Gnieźnieńskiej 33(1978) nr 5-6, s. 98-101. 
oświadczenie składają również rodzice żyjący bez ślubu kościelnego z powodu przeszkód kanonicznych. ${ }^{61}$ Norma ta, jak się wydaje, zawiera istotną sprzeczność. Jak bowiem można żądać od konkubinariuszy odmawiających przystępowania do sakramentów (małżeństwa, pokuty i Eucharystii) i przez to ukazujących swoje poważne braki w wierze, albo jej zupełny brak, katolickiego wychowania potomstwa? Czy rodzice, którym w poważnym stopniu wiary brakuje mogą ją przekazać innym? ${ }^{62}$ Osobowość budzi się w dziecku nie na skutek kontaktów ze światem rzeczy, ale jedynie przez obcowanie z drugą osobą, przez pełne miłości oddanie rodziców. To właśnie jest owa antropologiczna postawa, którą uwzględnia Kościół, uosabiając Chrystusa i udzielając chrztu niemowlętom niezdolnym do aktu wiary, nadziei, miłości i żalu, decydujących o owocności przyjmowanego sakramentu. ${ }^{63}$ Brak wiary rodziców, zazwyczaj nie może być zastąpiony wiarą innych osób, które na co dzień nie mają poważniejszego wpływu na wychowanie dzieci. W poprzednich stuleciach, kiedy rodziny były głównie wielopokoleniowe i chrzestni, których obowiązki często pełnili (i do dzisiaj pełnią) najbliżsi krewni chrzczonych dzieci, wszyscy mieszkali w tej samej lub pobliskiej chałupie, kamiennicy lub dworze. Byli więc oni w stanie uzupełniać albo nawet zastępować rodziców w religijnym wychowaniu potomstwa, przekazując swoją wiarę słowem i przykładem życia. Dzisiaj chrzestni mieszkają zazwyczaj daleko, nawet w innym kraju. Stąd ogromny wzrost znaczenia wiary rodziców, którzy sami muszą wychować po katolicku swoje dzieci.

Wydaje się zatem, że obowiązujące normy nie przystają już do panującej rzeczywistości. Zgodnie z nimi, przed chrzestnymi stawia się bowiem o wiele większe wymagania, niż przed rodzicami dziecka. W odniesieniu do tych drugich nie ma postanowień, które określałyby przynajmniej minimum, jakie według ustawodawcy kościelnego mogłoby zagwarantować możliwość rzeczywistego wychowania ochrzczonego potomstwa w wierze katolickiej. Przez analogię do

\footnotetext{
${ }^{61}$ Tamże, s. 98.

${ }^{62}$ Z. JANCZEWSKI, dz. cyt., s. 128.

${ }^{63}$ A. SkowroneK, dz. cyt., s. 20-21.
} 
norm odnoszących się do chrzestnych, wydaje się, że rodzice chcący ochrzcić swoje dziecko, a przynajmniej jeden z nich (poza niebezpieczeństwem śmierci dziecka), powinien spełniać następujące kryteria:

- przyjął bierzmowanie i Eucharystię, czyli wszystkie sakramenty wtajemniczenia chrześcijańskiego, aby mógł właściwie towarzyszyć w takim wtajemniczaniu w chrześcijaństwo swojego potomstwa,

- stara się prowadzić życie zgodne z wiarą, na ile mu na to ewentualnie pozwala niewierzący albo niechrześcijański współmałżonek, jeżeli z takim zawarł małżeństwo,

- nie zaciągnął kary kanonicznej, wymierzonej lub deklarowanej zgodnie z prawem.

Stawiając wymagania wobec rodziców chcących ochrzcić dziecko, Kościół może przyczynić się do podniesienia ,jakości” wiary swoich wyznawców, w czasach kiedy nawet w krajach tradycyjnie katolickich, jak Polska, niejako „przypadkowo”, „z tradycji” ochrzczone dzieci, nierzadko wyrastają na osoby obojętne religijnie, a nawet wrogie religii. Nie mając bowiem w praktyce żadnego wsparcia religijnego we własnej najbliższej rodzinie, wychowują się w środowisku laickim, a nie rzadko wrogim religii katolickiej.

\subsection{Chrzestni}

Jak to już zostało wspomniane, chrzestni w pierwszych wiekach chrześcijaństwa wprowadzali katechumenów w tajniki wiary, stanowiąc rękojmię jej przyjęcia. Reprezentowana przez nich instytucja, wyrosła z połączenia trzech funkcji: poręczyciela wiary dorosłego, pomocnika w obrzędach chrztu dzieci i osoby odpowiadającej w ich imieniu w czasie dialogu liturgicznego z szafarzem sakramentu. ${ }^{64}$ Również dzisiaj, zgodnie z dyspozycją Kodeksu prawa kanonicznego, mają oni dorosłemu towarzyszyć w chrześcijańskim wtajemniczeniu, a w przypadku dziecka, przedstawić je wraz z rodzicami do chrztu oraz pomagać, aby neofita prowadził życie zgodne z wymogami przyjętego

${ }^{64}$ B. NAdOLSKI, dz. cyt., s. 36. 
sakramentu. ${ }^{65}$ Wypełniając swoją funkcję, chrzestny w odniesieniu do dorosłego, powinien uczestniczyć przynajmniej w końcowych obrzędach katechumenatu oraz samym obrzędzie chrztu, w celu poświadczenia wiary przyjmującego. Natomiast w odniesieniu do dziecka występuje on jako przedstawiciel jego rodziny i Kościoła, podejmując zobowiązanie niesienia pomocy dziecku w wyznawaniu i poznawaniu wiary w jego życiu. ${ }^{66}$ Podczas ceremonii chrzcielnych wyznaje publicznie wiarę Kościoła, w której udzielany jest chrzest. Stąd nie należy do tej funkcji wybierać osób, które nie mogą szczerze złożyć tego wyznania. Norma liturgiczna podkreśla, iż należy o tym często pouczać wiernych, zwłaszcza przygotowując ich do małżeństwa, aby w przyszłości, przed chrztem, uniknąć nieprzyjemności. ${ }^{67}$ Tym bardziej, że oprócz wspomnianego wyznania wiary, chrzestni publicznie wyrzekają się zła, grzechu i szatana, co staje się jedynie pustą deklaracją, jeśli ich życie nie pokrywa się z deklarowaną wiarą.

Ustawodawca kościelny stawia przed chrzestnym konkretne wymagania. W odniesieniu do wyznawanej wiary musi on być katolikiem, a więc ochrzczonym w Kościele katolickim, albo do niego przyjętym po chrzcie w innej Wspólnocie chrześcijańskiej. Chodzi tutaj o fakt wyznawania tej samej wiary, w jakiej zostanie ochrzczony chrześniak. Ze względów ekumenicznych, zgodnie z dyrektorium Papieskiej Rady ds. Popierania Jedności Chrześcijan z 25 marca 1993 r., wyjątek stanowi dopuszczenie do pełnienia omawianej funkcji wiernego Kościoła prawosławnego, jako jednego z chrzestnych ${ }^{68}$ Drugi z nich, musi być jednak katolikiem, aby w pełni zagwarantować wychowanie dziecka w wierze katolickiej. ${ }^{69}$ Chrzestny ma wcześniej przyjąć bierzmowanie i Eucharystię, czyli wszystkie sakramenty wtajemniczenia chrześcijańskiego, posiadać pewną dojrzałość, suponowaną przez prawodawcę

${ }^{65}$ Kan. 872.

${ }^{66}$ J. KRZYWDA, dz. cyt., s. 59.

${ }^{67}$ Obrzędy chrztu dzieci..., s. 22-23.

${ }^{68}$ Directoire pour l'application des principes et des Normes sur l'Oecumenisme, $\mathrm{nr}$ 98 b, AAS 85(1993) s. 1076.

${ }^{69}$ G. Trevisan, Il battesimo, w: Codice di Diritto Canonico Commentato, a cura della Redazione di Quaderni di diritto ecclesiale, Milano 2009, s. 874. 
kościelnego po ukończeniu 16 lat, chyba że biskup diecezjalny określił inny wiek, lub też proboszcz albo szafarz są zdania, że słuszna przyczyna zaleca dopuszczenie wyjątku. ${ }^{70}$ Może się bowiem zdarzyć, że w niektórych rejonach świata, osoby są już bardziej dojrzałe w niższym wieku niż ich rówieśnicy, albo jako 16-latki nie dorosły jeszcze do podjęcia się tak ważnej funkcji. Chrzestny ma także prowadzić życie zgodne z wiarą i konsekwentnie z tym być wolnym od jakiejkolwiek kary kanonicznej, wymierzonej, albo deklarowanej. ${ }^{71}$

Uchwały II Polskiego Synodu Plenarnego, odbytego w latach 19911999, trafnie zauważają, że w Polsce wybór chrzestnego jest traktowany jako zaszczyt. W podejmowaniu tej funkcji zbyt często dużą rolę odgrywają motywy zwyczajowe i towarzyskie. ${ }^{72}$ Istota tej funkcji przechodzi więc gdzieś na dalszy plan, a czasem nawet zostaje zupełnie zagubiona. Chrzestny nie jest niekiedy w stanie służyć rodzicom dziecka wsparciem, w staraniu o to, aby doszło ono w przyszłości do wyznawania wiary i wyrażania jej własnym życiem. ${ }^{73}$ Instrukcja duszpasterska Episkopatu o udzielaniu sakramentu chrztu dzieciom z 1977 r. zakazuje dopuszczania do pełnienia interesującej nas funkcji osób żyjących w niesakramentalnym związku małżeńskim i młodzieży nieuczęszczającej na katechizację. Fakty te należy weryfikować przy pomocy odpowiednich zaświadczeń. Należy doradzać rodzicom, aby znajdowali chrzestnych wśród najbliższej rodziny i sąsiadów, a nie w gronie ludzi przygodnych, a za to dobrze sytuowanych, którzy w przyszłości nie będą się interesować chrześcijańskim wychowaniem dziecka. Od kandydatów na chrzestnych, którzy nie są znani duszpasterzowi, należy wymagać przedstawienia świadectwa kwalifikacyjnego, wystawionego przez ich własnego duszpasterza. ${ }^{74}$

Chociaż jak wskazuje doświadczenie, wpływ chrzestnych na wychowanie chrześcijańskie dzieci jest zazwyczaj niewielki albo, kiedy

${ }^{70}$ KPK83, kan. 874, par. 1, nr 2-3.

${ }^{71}$ Tamże, nr 3-4.

${ }^{72}$ Liturgia Kościoła po Soborze Watykańskim II, nr 59, w: II Polski Synod Plenarny (1991-1999), Poznań 2001, s. 200.

${ }^{73}$ Z. JANCZEWSKI, dz. cyt., s. 129.

${ }^{74}$ Dok. cyt., s. 100. 
mieszkają daleko, takiego wpływu w ogóle nie ma, przynajmniej na szacunek do wielowiekowej tradycji, należy pozostać przy wymogach, aby reprezentowali oni swoją postawą życie zgodne z wiarą Kościoła. Nieporozumieniem w obecnej sytuacji Kościoła katolickiego (przynajmniej w Europie), jest jak się jednak wydaje, stawianie przed nimi wyższych wymagań, niż przed rodzicami, mającymi rzeczywisty wpływ na takowe wychowanie.

\section{Zakończenie}

Wiara i chrzest wzajemnie się łączą. Nauczał o tym już sam Jezus Chrystus, mówiąc, że ten kto uwierzy i przyjmie omawiany sakrament będzie zbawiony. Chrześcijanie od początku istnienia Kościoła trzymali się tej prawdy. Chrzest osób dorosłych, bo taki przeważał w pierwszych wiekach, był poprzedzony katechumenatem, który miał nauczyć nowego sposobu życia, zgodnego z wiarą. Chrzestni dzielili się z katechumenem doświadczeniem własnej wiary. Przed przystąpieniem do sakramentu kandydat musiał wykazać się pozbyciem pogańskich obyczajów oraz umiejętnością życia po chrześcijańsku.

Czym jest zatem wiara, tak istotna dla przyjmującego chrzest? Według Nowego Testamentu polega ona na zetknięciu się człowieka z Chrystusem. Warunek stanowi tutaj metanoia, radykalna przemiana serca, wymagająca konsekwencji w naśladowaniu Jezusa. To relacja do Boga, obejmująca całego człowieka, z jego zewnętrznym zachowaniem i życiem duchowym. Wiara bowiem bez uczynków, jest martwa. Wyrazem chrześcijańskiego życia wiarą jest ciągła przemiana ku temu, co dobre i boże.

Osoby dorosłe, po usłyszeniu przepowiadania Ewangelii, pod wpływem działania Ducha św., otwierającego ich serca, świadomie i dobrowolnie szukają Boga i wstępując na drogę wiary, zgodnie z wielowiekową z praktyką Kościoła, rozpoczynają okres katechumenatu. Podczas dopuszczania ich do chrztu, najczęściej nie ma problemu z uznaniem, że posiadają wymaganą wiarę. Weryfikacja następuje właśnie podczas katechumenatu, kiedy to istnieje wystarczająca ilość czasu, aby się przypatrzeć kandydatom. Ponadto wola zostania chrześcijaninem, zostaje zazwyczaj poprzedzona wzbudzeniem aktu wiary. 
Z trudniejszą sytuacją mamy do czynienia w przypadku dziecka, przynoszonego do pierwszego z sakramentów wtajemniczenia chrześcijańskiego. Nie posiada ono jeszcze rozwiniętej wiary, jak dorosły. Dziecko otrzymuje zatem chrzest w wierze swoich rodziców, chrzestnych i Kościoła. Stąd u rodziców, a przynajmniej u jednego z nich, powinna istnieć autentyczna wiara. Kościół stoi na jej straży dopuszczając do chrztu i go udzielając, a także stawiając wymagania proszącym o ten sakrament dla swojego potomstwa. U podstaw tych wymagań znajduje się ścisły związek chrztu z wiarą, stąd duszpasterze mają prawo i obowiązek badania, czy zachodzą rzeczywiste przesłanki ku istnieniu uzasadnionej nadziei katolickiego wychowania dzieci w wierze. Wychowanie bez niej, będzie skutkowało w przyszłości brakiem owocności sakramentu, w którym otrzymywane łaski, a przynajmniej ich część, wymagają podłoża wiary.

Z punktu widzenia kanonisty wydaje się, że obowiązujące normy nie przystają już do rzeczywistości, w jakiej przychodzi żyć współczesnym katolikom, szczególnie w krajach wysoko rozwiniętych. Zgodnie z prawem, przed chrzestnymi stawia się bowiem większe wymagania, niż przed rodzicami dziecka. W odniesieniu do rodziców nie ma postanowień, określających przynajmniej minimum, jakie w przekonaniu ustawodawcy kościelnego mogłoby zagwarantować możliwość rzeczywistego, a nie domniemanego, wychowania chrzczonego potomstwa w wierze Kościoła katolickiego. Stawiając wymagania można przyczynić się do podniesienia ,jakości” wiary przyszłych wyznawców, szczególnie w czasach, kiedy w krajach tradycyjnie katolickich, dzieci nierzadko chrzci się dla tradycji, niejako ,przypadkowo”, po czym wyrastają one na osoby obojętne religijnie, albo nawet wrogie religii.

Chrzestny występujący podczas ceremonii chrztu dorosłego, zgodnie z wymogami prawa, powinien uczestniczyć przynajmniej w końcowych obrzędach katechumenatu oraz w ceremonii chrztu, poświadczając wiarę przyjmującego. W przypadku chrztu dziecka, występuje jako przedstawiciel jego rodziny i Kościoła, zobowiązując się do niesienia pomocy w poznawaniu i wyznawaniu wiary. Ustawodawca stawia 
przed chrzestnym konkretne, precyzyjnie sformułowane wymagania. Jak wskazuje doświadczenie życiowe, wpływ chrzestnego na chrześcijańskie wychowanie dzieci jest zazwyczaj nikły, albo przy większych odległościach miejsc zamieszkania, takiego wpływu nie ma w ogóle. Zgodnie z tradycją Kościoła należy pozostać przy wspomnianych wymogach, aby swoją postawą życiową chrzestny reprezentował życie zgodne z wyznawaną wiarą.

\section{The faith as fundamental condition to take the baptism}

The faith and the baptism are inseparable. In the beginning of history of the church the baptism was taking adult people. They has the faith before this sacrament. The children was baptizing together with his parents. Today in many countries candidates to baptism are children, to young, to have mature faith. They take sacrament on the faith of their father, mother, sponsors and Church.

The article consists of three parts. First is about historical aspect of the problem. The next shows theological conception of the faith. The last part is about faith of adult people who takes the sacrament of baptism, and parents and sponsors of children who takes the baptism, based on canon and liturgical law. 